\title{
Work engagement and job burnout? Roles of regulatory foci, supervisors' organizational embodiment and psychological ownership
}

\author{
Authors \\ You-De Dai, Levent Altinay, Wen-Long Zhuang, Kuan-Tai Chen
}

\begin{abstract}
The study explores the impact of promotion focus/prevention focus on the work engagement/job burnout of international tourist hotel employees, and in the meantime compare the influence of promotion focus and prevention focus. Moreover, the study explores as well whether supervisors' organizational embodiment and psychological ownership serves as moderators in the relationship between promotion focus/prevention focus and work engagement/job burnout of international tourist hotel employees. Based on an analysis of 716 employees of international tourist hotel, this study found promotion focus and prevention focus were positively related to work engagement and job burnout; promotion focus and prevention focus were negatively related to work engagement and job burnout. Moreover, prevention focus accounted for more variance in work engagement and job burnout than did that of promotion focus. Psychological ownership moderates the relationship between regulatory foci and work engagement. Psychological ownership also moderates the relationship between regulatory foci and job burnout.
\end{abstract}

Keywords: Regulatory focus, supervisors' organizational embodiment, psychological ownership, work engagement, job burnout 


\section{Introduction}

Hospitality and tourism industries tend to be labor-intensive, and frontline employees are confronted with quite a few job requirements (Lin, Huang, Yang, \& Chiang, 2014). Can these employees maintain their work enthusiasm in such a working environment? Not surprisingly, Pang, Kucukusta and Chan (2015) have pointed out that the hotel and tourism industry in particular will face the challenge of shortage of human resources. In addition, meeting customer needs is a challenge that only highly motivated employees can accomplish (Li, Sanders, \& Frenkel, 2012). Front-line employees always interact with customers, they are expected to be sensitive and positive to meet customers' needs. As a result, highly engaged employees become an important element in maintaining good service (Guan, Yeh, Chiang, \& Huan, 2020; Li et al., 2012).

Notably, burnout is the most studied variable in many negative meanings (e.g., Brotheridge \& Grandey, 2002; Johnson \& Spector, 2007; Mansour \& Tremblay, 2016; Montgomery, Panagopolou, de Wildt, \& Meenks, 2006; Walters \& Raybould, 2007). Burnout is essentially the worker's overall perception of reciprocity in terms of salary dissatisfaction and the recognition, support, and promotion that has not met expectations (Grobler, Wärnich, Carrell, Elbert, \& Hatfield, 2002). Failure to improve an individual's burnout can mean a loss of productivity or quality in their work, as well as lower morale, mental or physical health (Pienaar \& Willemse, 2008).

In order to get the hotel operating smoothly, the hotel owner must think on what type of employee will have a high work engagement (Altinay, Dai et al., 2019; Karatepe, Keshavarz, $\&$ Nejati, 2010) or will not have a job burnout? Noticeably, regulatory focus theory (Higgins, 1996, 1997) introduced two strategies to achieve the goal, namely, promotion focus and prevention focus. Individual promotion focus takes hope and desire as the goal, while 
individual prevention focus takes responsibility and obligation as the goal. These two foci assume that the individual will adopt the eager or vigilant strategies to achieve the goal. Eager strategy ensures that a positive result is available and avoids the lack of a positive result. Vigilant strategy is to make sure there are no negative results and prevent them from happening (Higgins, Friedman et al. 2001). In conclusion, promotion focus of hotel employees will drive them to expect to complete work tasks, while prevention focus of hotel employees is to urge them to regard assignment of tasks as responsibilities and obligations. The promotion focus or prevention focus orientation of the employees are very important for the work engagement and job burnout, as the hoteliers are trying to improve employees' work engagement (Altinay et al., 2019) and reduce their job burnout. Surprisingly, there seems to be no relevant research on these phenomena. Accordingly, can the two regulatory foci of hotel employees affect their work engagement and job burnout? This is the first research question of this study. Although both promotion focus and prevention focus may affect the work engagement and job burnout of hotel employees, which of the two focus orientations has the greater influence? At present, relevant research is still quite lacking. Therefore, it seems to be a topic worth discussing to compare the influences of promotion focus and prevention focus on work engagement and job burnout for hotel employees. This is the second research question of this study.

However, although hotel employees' promotion focus and prevention focus may affect their work engagement and job burnout, will the above relations be different due to situational factors? In the process of social exchange, there are two social psychological mechanisms: reciprocity norm and perception of performance-reward expectation (Blau, 1964; Eisenberger, Armeli, Rexwinkel, Lynch, \& Rhoades, 2001). Organizational support theory holds that supervisors play a key role in the social exchange between employees and their organizations (Eisenberger, Huntington, Hutchison, \& Sowa, 1986; Eisenberger, Karagonlar et al. 2010). As for the relationship between employees and their organizations, existing theories mainly focus 
on how employees view the organizational agents played by their supervisors. In addition, the psychological perception of possessions leads individuals to see tangible or intangible goals as extensions of themselves (Belk, 1988; Dittmar, 1992). From the standpoint of employees, their psychological ownership of the organization will affect their implementation of the organization's goals. However, will the supervisors' organizational embodiment and the psychological ownership of the organization be important situational variables in the relationship between the hotel employees' promotion focus/prevention focus and their work engagement/job burnout? There seems to be no relevant research in the past to discuss this, and this is the third research question to be discussed in this study.

Basing on the perspective of interactionism, behavior is the outcome of personality intercating with situational factors. (Diener, Larsen, \& Emmons, 1984; Endler \& Edwards, 1986). Based on this viewpoint, this study intends to discuss the effects of hotel employees' promotion focus/prevention focus on their work engagement/job burnout and the comparison of the influences between promotion focus and prevention focus. Finally, this study also explores whether supervisors' organizational embodiment and employees' psychological ownership (situational factor) play the roles of moderating effect on the relationship between promotion focus/prevention focus (personality factor) and work engagement/job burnout (behavior). 


\section{Literature Review}

Work Engagement

Schaufeli, Salanova, Gonzáles-Romá and Bakker (2002) define work engagement as “a positive, ambitious, work-related mental state characterized by vigor, dedication, and absorption". Work engagement is related to the activation and optimal functioning of wellbeing in the workplace (Christian, Garza, \& Slaughter, 2011). In recent years, a growing number of hospitality management study investigated the employees' work engagement (e.g., Altinay et al., 2019; Karatepe, Beirami, Bouzari, \& Safavi, 2014).

\section{Job Burnout}

The concept of job burnout was first proposed by Freudenberger (1974), describing employees who are generally engaged in interpersonal work. Due to long-term energy loss, the enthusiasm for work gradually disappears, and then a phenomenon of indifference to people and negative attitudes towards work (Maslach \& Jackson, 1984). Kalimo, Pahkin, Mutanen and ToppinenTanner (2003) pointed out that job burnout implies a state of mental fatigue, which can be regarded as an extension of negative psychological feelings and work stress results. When individual's work requirements and abilities are unbalanced for a period of time, job burnout occurs. (e.g., Lin et al., 2014; Prentice, Chen, \& King, 2013).

\section{Regulatory Foci and Work Engagement}

Are every hotel staff willing to work hard and meet customer needs? According to regulatory focus theory (Higgins, 1996, 1997), for the tasks assigned by the company, in order to avoid situations where they are not dedicated enough to meet the needs of the customers, the promotion focus of hotel employees helps to adjust their mentality to try their best to complete the tasks, thereby increasing their work engagement. On the other hand, the hotel employees' 
prevention focus can encourage them to fear that they will not be dedicated to work, and will be more aggressive in their work. However, hotel employees' promotion focus may prompt them to actively ask the service needs of the service customers. On the contrary, the hotel employees' prevention focus is likely to satisfy the customers' common complaints, and even do their homework beforehand to avoid the situation of inadequate service. Therefore, it seems that prevention focus is more helpful for hotel employees to put more effort into their work. Accordingly, this study proposes the following hypotheses:

H1: The stronger employees' promotion focus and prevention focus are, the higher their work engagement will be.

H2: Prevention focused employees have higher work engagement than promotion focused employees.

\section{Regulatory Foci and Job Burnout}

Whether employees have job burnouts may be examined in terms of their personality. When the hotel employees' works are completed, the promotion focus of the hotel employees will ensure that the overall customer service has a better service quality, and they will actively assist the customer to improve the hotel's operating efficiency. In order to ensure that customers are not dissatisfied with the imperfect services of other colleagues, promotion focused employees will also carefully review the work for imperfections after completing the work at hand, thus greatly reducing the possibility of job burnout. However, promotion focused employees may want to see that the entire company's operations are smooth, and the focus should be on completing additional work items. On the contrary, prevention focused employees do not want to see that the hotel operation is not smooth. The focus will be on carefully examining the imperfections in the work. It can be seen that the promotion focus of hotel employees is likely to increase their extra workload. Instead, the hotel's employees' prevention 
focus will motivate them to do their job properly, with the principle of not making mistakes. Therefore, it seems that prevention focus is more helpful for hotel staff to reduce the likelihood of their job burnout. Accordingly, this study proposes the following hypotheses:

H3: The stronger employees' promotion focus and prevention focus are, the higher their job burnout will be.

H4: Prevention focused employees have lower job burnout than promotion focused employees.

\section{Moderating Role of Supervisors' Organizational Embodiment}

From the perspective of regulatory focus theory, the work engagement of hotel employees may be affected by promotion focus and prevention focus. From the perspective of interactionism (Diener et al., 1984; Endler \& Edwards, 1986), the work engagement of hotel employees may be the result of the interaction between regulatory foci (personality factor) and supervisors' organizational embodiment (situational factor). When the supervisors' organizational embodiment is high, the hotel staff understands that any decision made by their superiors represents the company, and the more they can integrate into their work tasks, the promotion focus or prevention focus of these employees may have an enhanced effect on improving their work engagement. In contrast, in the case of low supervisors 'organizational embodiment, it is difficult for hotel employees to integrate into their work tasks. In this case, the hotel employees will think that what the supervisors said needs to be discounted, so the promotion focus or prevention focus of these employees may have a suppressive effect on improving their work engagement. Accordingly, this study proposes the following hypotheses:

H5: Supervisors' organizational embodiment has a moderating effect on the relationship between promotion focus and work engagement. 
H6: Supervisors' organizational embodiment has a moderating effect on the relationship between prevention focus and work engagement.

Similarly, according to regulatory focus theory, promotion focus and prevention focus may reduce job burnout of hotel employees. According to interactionism, the job burnout of hotel staff may be the result of the interaction between regulatory foci (personality factor) and supervisors' organizational embodiment (situational factor). In the case of high supervisors 'organizational embodiment, hotel employees are working harder and harder, so the promotion focus or prevention focus of these employees will have an enhanced effect on reducing their job burnout. On the contrary, when the supervisors 'organizational embodiment is low, hotel employees are likely to be inattentive to work, so their promotion focus or prevention focus will be suppressed to reduce their job burnout. Accordingly, this study proposes the following hypotheses:

H7: Supervisors' organizational embodiment has a moderating effect on the relationship between promotion focus and job burnout.

H8: Supervisors' organizational embodiment has a moderating effect on the relationship between prevention focus and job burnout.

\section{Moderating Role of Psychological Ownership}

According to regulatory focus theory, the work engagement of hotel employees may be affected by promotion focus and prevention focus. From the perspective of interactionism, the work engagement of hotel staff may be the result of the interaction between regulatory foci (personality factor) and psychological ownership (situational factor). When psychological ownership is high, hotel employees think this company is where they want to stay. The promotion focus of employees is to get things done as soon as possible, which may have little 
effect on improving their work engagement. The prevention focus of employees values staying in the company steadily, which may have a strengthening effect on improving their work engagement. On the other hand, with low psychological ownership, hotel employees believe that the company has not yet reached their ideal operating conditions. Employees' promotion focus will make them think that their efforts are not structured. The employee's prevention focus will be afraid of their poor performance and will be reviewed. This may have an effect on improving their work engagement. Accordingly, this study proposes the following hypotheses:

H9: Psychological ownership has a moderating effect on the relationship between promotion focus and work engagement.

H10: Psychological ownership has a moderating effect on the relationship between prevention focus and work engagement.

Similarly, according to regulatory focus theory, promotion focus and prevention focus may reduce job burnout of hotel employees. According to interactionism, the job burnout of hotel employees may be the result of interaction between regulatory foci (personality factor) and psychological ownership (situational factor). With high psychological ownership, hotel employees see the company they are staying in as a place of long service. In such a stable situation, the promotion focus of these employees can easily allow them to complete the work quickly, and complete the extra work, so they cannot reduce their job burnout. The prevention focus of employees is to do what they should do. The principle of not making mistakes is very helpful to reduce their job burnout. On the other hand, with low psychological ownership, hotel employees are likely to believe that their performance has not yet been recognized by the company. In this situation, promotion focus or prevention focus of these employees can 
effectively improve their job burnout. Accordingly, this study proposes the following hypotheses:

H11: Psychological ownership has a moderating effect on the relationship between promotion focus and job burnout.

H12: Psychological ownership has a moderating effect on the relationship between prevention focus and job burnout.

\section{Methodology}

\section{Research Framework}

This study proposes hotel employees' promotion focus and prevention focus are helpful for improving their work engagement and reducing their job burnout; Compared with prevention focus, employee' promotion focus is much better for improving work engagement and reducing job burnout; supervisors' organizational embodiment has a moderating effect on relationship between employees' regulatory foci (promotion focus and prevention focus) and their work engagement/job burnout. Figure 1 is the framework of this study.

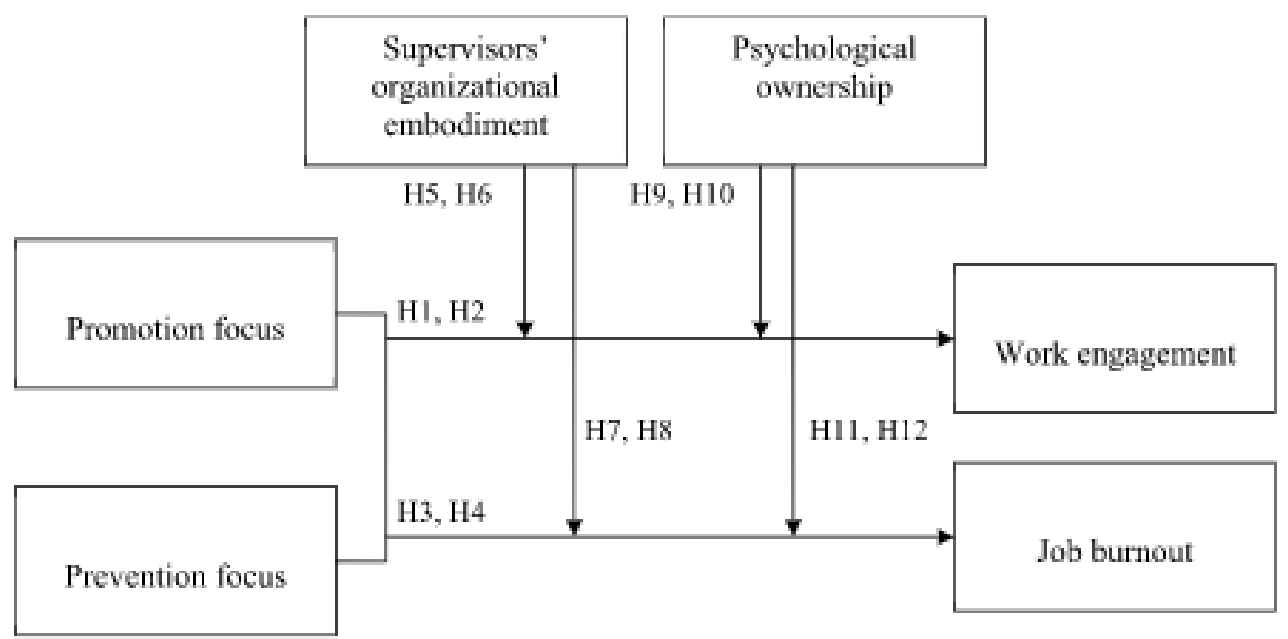

Fig. 1. Conceptual framework. 


\section{Sampling}

This study was conducted with the participation of employees who worked for ten fivestar hotels in Taipei, Taichung, Kaohsiung, Xiamen and Quanzhou. Travelers visit these cities both for business and leisure purposes with high expectations regarding customer service. Therefore, hotel employees are expected to strive for service excellence, which makes five-star hotels more suitable in this study. The questionnaire collection period is from January to May 2018. Judgmental sampling method was adopted in the study. The survey data was collected from hotel employees and the questionnaires were designed: a cover letter described the survey process, made certain the voluntary nature of the study, and told participants to have the filled out questionnaires sealed in the return envelopes.

In addition, before the questionnaire was formally distributed, to reduce the effects of social expectations, this study adopted the practices of Podsakoff, MacKenzie, and Podsakoff (2012). First of all, respondents were told that the questionnaire was for academic purposes only. Second, the respondent understood that the questionnaire was answered anonymously, and no one except the author was to know the identity of the respondent. Third, the respondents were told that the questionnaire was a holistic analysis not an individual analysis. Fourth, the respondent was free to discontinue the process of answering questions. Finally, the author collected completed questionnaires to eliminate the respondents' concerns regarding the exposure of their answers.

\section{Measurement}

Measurement of regulatory focus is based on the scale (twelve items) developed by Wallace and Chen (2006). Measurement of work engagement is based on the scale (nine items) 
developed by Schaufeli, Bakker and Salanova (2006). Measurement of job burnout is based on the scale (four items) developed by Maslach and Jackson (1986). Measurement of supervisors' organizational embodiment is based on the scale (five items) developed by Eisenberger, Shoss et al. (2014) and Shoss, Eisenberger, Restubog and Zagenczyk (2013). Measurement of psychological ownership is based on the scale developed by Pierce, Kostova and Dirks (2001), Van Dyne and Pierce (2004) and Han, Chiang and Chang (2010), and in which the items are revised to meet the requirements of the study. All measurements are based on 5-point Likert scale with anchors ranging from 1 (strongly disagree) to 5 (strongly agree).

\section{Results}

\section{Respondent Profile}

A total of 1500 questionnaires were distributed in this study, including international tourist hotels in Taipei, Taichung, Kaohsiung, Xiamen and Quanzhou. 300 were issued in each of the five regions, and a total of 792 were recovered. 76 invalid questionnaires were deducted, and 716 were valid questionnaires. The effective response rate was $47.73 \%$. The deduction conditions for invalid questionnaires are incomplete responses, blanks, missed answers, multiple selections, failure to meet the sampling criteria, and all scores of the response questionnaires are similar. This study considers such questionnaires to be invalid questionnaires. The analysis results of the samples showed that the majority of the subjects were mainly females (65.50\%); the age was mostly between 19 and 24 years old $(42.20 \%)$; in terms of position, the majority of the subjects were mainly grassroots staff, totaling 365 people, accounting for $51.00 \%$ of the total sample; in tenure, most of the participants have less than 1 year of experience $(39.40 \%)$. 


\section{Reliability Analyses}

This study used a Cronbach's $\alpha$ value of greater than 0.70 and the revised item-total correlation value of greater than 0.45 as the measurement criteria. The reliability of each factor measurement question is: Cronbach 's $\alpha$ value of promotion focus is 0.93 ; Cronbach 's $\alpha$ value of prevention focus is 0.92 ; Cronbach 's $\alpha$ value of supervisors' organizational embodiment is 0.95; Cronbach 's $\alpha$ value of psychological ownership is 0.92 ; Cronbach 's $\alpha$ value for work engagement is 0.95 ; Cronbach 's $\alpha$ value for emotional exhaustion is 0.97 ; Cronbach 's $\alpha$ value for depersonalization is 0.92 ; Cronbach 's $\alpha$ value for reduced personal accomplishment is 0.97 . Each construct of the questionnaire in this study has high reliability.

\section{Confirmatory Factor Analyses}

In this study, first-order confirmatory factor analysis was performed, and the analysis results showed (see Table 1), $\chi^{2}=4469.482, d f=1196, \mathrm{RMSEA}=0.06, \mathrm{CFI}=0.92, \mathrm{IFI}=0.92$. Each indicator has an acceptable degree of fit. This study tested the validity of the scale by confirmatory factor analysis (see Table I for details). In terms of the scale validity, the study adopted a factor load of less than 0.4 as the criterion for deletion (Hair, Anderson, Tatham, \& Black, 1998). No items were deleted, and all 51 variables reached a significant level $(t>1.96$, $p<0.05)$. When the factor load is significant and has high composition reliability (CR), the scale has convergence validity (Bagozzi \& Yi, 1988) and the average variance extracted (AVE) between latent variables and all corresponding measurements are more than 0.50 , which also means that the scale has convergence validity (Bagozzi \& Yi, 1988). The AVE values of the scales/constructs used in this study were 0.68 for promotion focus的, 0.67 for prevention focus, 0.81 for supervisors' organizational embodiment, 0.80 for psychological ownership, 0.70 for work engagement, 0.79 for emotional exhaustion, 0.70 for depersonalization and 0.81 for 
reduced personal accomplishment. Fornell and Larker (1981) suggested that the AVE value must be greater than 0.50 . If the AVE value is less than 0.50 , it means that the variation is greater than $50 \%$ and the convergence validity is not sufficient. All AVE values of each scale/construct in this study were greater than 0.5 to a significant level, so the study scale had an acceptable convergence validity.

If the two constructs are tested using correlation analysis and if their correlation degree is very low, then these two constructs have discriminant validity (Anderson \& Gerbing, 1988; Fornell \& Larcker, 1981). Moreover, the decision criterion is that the square root of AVE values of each construct must be greater than the correlation coefficient between the construct and other constructs (Hair et al., 1998). The test results of discriminant validity reveal that each square root of AVE values is between 0.82 and 0.90 (refer to Table 2), which is greater than the correlation coefficient between the constructs. This finding indicates that the scale used in the study has high discriminant validity.

\section{Table 1}

First-order confirmatory factor analysis results.

\begin{tabular}{lllll}
\hline Items & SFL & $\begin{array}{l}\text { t- } \\
\text { value }\end{array}$ & AVE & CR \\
\hline Promotion focus & & & 0.68 & 0.93 \\
I can always do a lot of work & 0.82 & - & & \\
Anyway, I have to finish my work & 0.83 & 26.50 & & \\
can do a lot of work in a short time & 0.83 & 26.64 & & \\
Work tasks can make me better at work & 0.84 & 27.09 & & \\
I often wonder if my work is done & 0.80 & 24.97 & & \\
I always think about how much work I can & 0.82 & 26.00 & & \\
$\quad$ & & & &
\end{tabular}


Prevention focus

$0.67 \quad 0.93$

I often follow the rules to work

0.81

I often complete work tasks correctly

$0.86 \quad 27.10$

I always do my job duty

$0.86 \quad 27.14$

When working, I often think of my duties

$0.81 \quad 25.06$

I often finish my job

$0.78 \quad 23.77$

I often notice work details

$0.80 \quad 24.38$

Supervisors' organizational embodiment

My supervisor has the spirit of the company

$0.81 \quad 0.95$

My supervisor has many similarities with my

0.89

$0.91 \quad 36.92$

company

My supervisor and the company have the same

0.89

35.32 standards for me

My supervisor can represent my company

$0.90 \quad 36.20$

My supervisor is very similar to my company

$0.90 \quad 36.00$

Psychological ownership

0.80

0.92

I think the company I am staying with is my

0.88 company

I think the success or failure of the company, I am

$0.91 \quad 33.76$ deeply involved

I would like to see the company as my home

$0.89 \quad 33.10$

Work engagement

$0.70 \quad 0.95$

I am motivated at work

0.86

In my job position, I consider myself handy and

$0.84 \quad 29.07$ energetic

I am passionate about my work

$0.89 \quad 32.87$

My job inspired me

$0.89 \quad 32.47$

When I get up in the morning, I really want to go

$0.77 \quad 25.62$

to work

I feel happy when I am busy with work $\quad 0.84 \quad 29.62$

I am proud of my work

$0.86 \quad 30.46$

I am very focused on my work

$0.81 \quad 27.55$

I overdo it at work

$0.77 \quad 25.56$ 
Emotional exhaustion

My job makes me tired

$0.87-$

I feel exhausted after work

$0.87 \quad 33.39$

When I got up, I was tired of thinking about what

$0.89 \quad 34.77$

I am doing today

Working with the crowd all day makes me feel

$0.91 \quad 36.33$ tired

I'm tired of my work

$0.93 \quad 38.57$

I am frustrated with my work

$0.92 \quad 37.53$

I think my work is hard

$0.88 \quad 33.68$

Working with people puts me under a lot of

$0.90 \quad 35.50$ pressure

I think I have reached the limit

$0.80 \quad 28.39$

Depersonalization

I have a hard time understanding how others feel

0.83

0.70

0.92

I can't deal effectively with other people's

$0.86 \quad 28.24$ problems

I feel that my work cannot have a positive impact

$0.84 \quad 27.04$ on others

I don't think I have enough energy

$0.85 \quad 27.43$

It's not easy for me to create a relaxed

$0.81 \quad 25.76$

atmosphere with others

Reduced personal accomplishment

$0.81 \quad 0.97$

Whenever I have close contact with others, I

0.88 cannot feel happy

\begin{tabular}{|c|c|c|c|c|}
\hline Items & SFL & $\begin{array}{l}\mathrm{t}- \\
\text { value }\end{array}$ & AVE & CR \\
\hline I rarely accomplish anything of value in this job & 0.89 & 35.83 & & \\
\hline $\begin{array}{l}\text { I can't calmly deal with my emotional problems } \\
\text { at work }\end{array}$ & 0.90 & 36.39 & & \\
\hline I think my attitude towards some people is cold & 0.90 & 36.99 & & \\
\hline $\begin{array}{l}\text { After I got this job, I became less emotional about } \\
\text { others }\end{array}$ & 0.93 & 40.15 & & \\
\hline $\begin{array}{l}\text { I worry that this job will make me more and more } \\
\text { ruthless }\end{array}$ & 0.93 & 40.19 & & \\
\hline I don't care what happened to others & 0.91 & 37.92 & & \\
\hline I think others blame me for their own problems & 0.88 & 34.69 & & \\
\hline
\end{tabular}

Note: SFL: standardised factor loading; AVE: average variance extracted; CR: composite reliability. 
Table 2

Mean, standard error, square root of AVE and correlation coefficients.

\begin{tabular}{|c|c|c|c|c|c|c|c|c|c|c|}
\hline Variables & Mean & Standard error & A & B & $\mathrm{C}$ & $\mathrm{D}$ & $\mathrm{E}$ & $\mathrm{F}$ & G & $\mathrm{H}$ \\
\hline A. Promotion focus & 4.01 & 0.63 & $\begin{array}{l}0.82 \\
1\end{array}$ & & & & & & & \\
\hline B. Prevention focus & 4.08 & 0.62 & 0.81 & $\begin{array}{l}0.82 \\
1\end{array}$ & & & & & & \\
\hline C. Supervisors' organizational embodiment & 3.93 & 0.73 & 0.46 & 0.45 & $\begin{array}{l}0.90 \\
1\end{array}$ & & & & & \\
\hline D. Psychological ownership & 3.46 & 0.83 & 0.41 & 0.39 & 0.43 & $\begin{array}{l}0.89 \\
1\end{array}$ & & & & \\
\hline E. Work engagement & 3.80 & 0.73 & 0.66 & 0.69 & 0.47 & 0.47 & $\begin{array}{l}0.84 \\
1\end{array}$ & & & \\
\hline F. Emotional exhaustion & 2.44 & 0.77 & -0.29 & -0.29 & -0.23 & -0.25 & -0.28 & $\begin{array}{l}0.89 \\
1\end{array}$ & & \\
\hline G. Depersonalization & 2.27 & 0.74 & -0.34 & -0.38 & -0.30 & -0.20 & -0.37 & 0.70 & $\begin{array}{l}0.84 \\
1\end{array}$ & \\
\hline H. Reduced personal accomplishment & 2.15 & 0.75 & -0.35 & -0.36 & -0.28 & -0.20 & -0.37 & 0.63 & 0.81 & $\begin{array}{l}0.90 \\
1\end{array}$ \\
\hline
\end{tabular}

Note: The value of the diagonal (the bold part of the slash) represents the square root of AVE, and the numerical value below the diagonal is the standardised correlation coefficient. 


\section{Hypothesis Testing}

Table 3 shows that both promotion focus and prevention focus have significant effects on work engagement $(\beta=0.27, \mathrm{p}<0.001 ; \beta=0.45, \mathrm{p}<0.001)$. Therefore, hypothesis 1 is supported. In addition, according to the above analysis results, the prediction ability of prevention focus is higher than that of promotion focus. Therefore, hypothesis 2 is supported.

\section{Table 3}

Multiple regression analysis of regulatory foci for work engagement.

\begin{tabular}{ll}
\hline Independent Variables & Dependent variable \\
\cline { 2 - 2 } & Work engagement $(\beta)$ \\
\hline Gender & 0.05 \\
Age & -0.02 \\
Position & 0.04 \\
Tenure & $0.10^{\text {*k }}$ \\
Promotion focus & $0.27^{* k \cdot k}$ \\
Prevention focus & $0.45^{* k * k}$ \\
$\mathrm{R}^{2}$ & 0.52 \\
Adj-R & 0.52 \\
$\mathrm{~F}$ & $128.22^{* k * k}$ \\
\hline
\end{tabular}

Note: $\mathrm{N}=716 ;{ }^{* *} \mathrm{p}<0.01,{ }^{* * *} \mathrm{p}<0.001$.

Table 4 shows that both promotion focus and prevention focus have significant effects on job burnout $(\beta=-0.14, p<0.05 ; \beta=-0.27, p<0.001)$. Therefore, hypothesis 3 is supported. In addition, according to the above analysis results, the prediction ability of prevention focus is higher than that of promotion focus. Therefore, hypothesis 4 is supported. 
Table 4

Multiple regression analysis of regulatory foci for job burnout.

\begin{tabular}{ll}
\hline Independent Variables & \multicolumn{1}{c}{ Dependent variable } \\
\cline { 2 - 2 } & Job burnout $(\beta)$ \\
\hline Gender & $-0.13^{* k *}$ \\
Age & -0.04 \\
Position & -0.03 \\
Tenure & $0.09^{*}$ \\
Promotion focus & $-0.14^{*}$ \\
Prevention focus & $-0.27^{* k *}$ \\
$\mathrm{R}^{2}$ & 0.18 \\
Adj-R & 0.17 \\
$\mathrm{~F}$ & $25.69^{* k *}$ \\
\hline
\end{tabular}

Note: $\mathrm{N}=716 ;{ }^{*} \mathrm{p}<0.05$, *k* $\mathrm{p}<0.001$.

Table 5 shows that the interaction between regulatory foci (promotion focus and prevention focus) and supervisors' organizational embodiment fail to predict work engagement $(\beta=0.02, p>0.05 ;(\beta=-0.04, p>0.05)$, this means supervisors' organizational embodiment has no moderating effect on the relationship between regulatory foci (promotion focus and prevention focus) and work engagement. Therefore, hypothesis 5 and hypothesis 6 are not supported.

Table 5

Regression results for moderating role of Supervisors' organizational embodiment in the relationship between regulatory foci and work engagement.

\begin{tabular}{|c|c|}
\hline \multirow[t]{2}{*}{ Independent Variables } & \multirow{2}{*}{$\begin{array}{l}\text { Dependent variable } \\
\text { Work engagement }(\beta)\end{array}$} \\
\hline & \\
\hline Gender & 0.05 \\
\hline Age & -0.03 \\
\hline Position & 0.04 \\
\hline Tenure & $0.11^{* k *}$ \\
\hline Promotion focus & $0.22^{* k *}$ \\
\hline Prevention focus & $0.41^{* k *}$ \\
\hline Supervisors' organizational embodiment & $0.17^{* k * k}$ \\
\hline Promotion focus*supervisors' organizational embodiment & 0.02 \\
\hline Prevention focus*supervisors' organizational embodiment & -0.04 \\
\hline $\mathrm{R}^{2}$ & 0.54 \\
\hline Adj- $R^{2}$ & 0.54 \\
\hline $\mathrm{F}$ & $93.77^{*-k *}$ \\
\hline
\end{tabular}

Note: $\mathrm{N}=716 ;{ }^{* * *} \mathrm{p}<0.001$. 
Table 6 shows that the interaction between regulatory foci (promotion focus and prevention focus) and supervisors' organizational embodiment fail to predict job burnout ( $\beta=-$ $0.08, \mathrm{p}>0.05 ;(\beta=0.08, \mathrm{p}>0.05)$, this means supervisors' organizational embodiment has no moderating effect on the relationship between regulatory foci (promotion focus and prevention focus) and job burnout. Therefore, hypothesis 7 and hypothesis 8 are not supported.

\section{Table 6}

Regression results for moderating role of Supervisors' organizational embodiment in the relationship between regulatory foci and job burnout.

\begin{tabular}{|c|c|}
\hline \multirow[t]{2}{*}{ Independent Variables } & \multirow{2}{*}{$\frac{\text { Dependent variable }}{\text { Job burnout }(\beta)}$} \\
\hline & \\
\hline Gender & $-0.13^{k-k \cdot k}$ \\
\hline Age & -0.04 \\
\hline Position & -0.02 \\
\hline Tenure & $0.08^{*}$ \\
\hline Promotion focus & -0.11 \\
\hline Prevention focus & $-0.24^{*-k-k}$ \\
\hline Supervisors' organizational embodiment & $-0.14^{*-k \cdot k}$ \\
\hline Promotion focus ${ }^{*}$ supervisors' organizational embodiment & -0.08 \\
\hline Prevention focus*supervisors' organizational embodiment & 0.08 \\
\hline $\mathrm{R}^{2}$ & 0.20 \\
\hline Adj- $R^{2}$ & 0.19 \\
\hline $\mathrm{F}$ & $19.01^{\frac{1 * k \cdot k}{2}}$ \\
\hline
\end{tabular}

Note: $\mathrm{N}=716 ;{ }^{*} \mathrm{p}<0.05$, *** $\mathrm{p}<0.001$.

Table 7 shows that the interaction between regulatory foci (promotion focus and prevention focus) and psychological ownership significantly predicts work engagement $(\beta=-$ $0.16, \mathrm{p}<0.01 ; \beta=0.13, \mathrm{p}<0.01)$, this means psychological ownership has a moderating effect on the relationship between regulatory foci (promotion focus and prevention focus) and work engagement. 


\section{Table 7}

Regression results for moderating role of psychological ownership in the relationship between regulatory foci and work engagement.

\begin{tabular}{|c|c|}
\hline \multirow[t]{2}{*}{ Independent Variables } & \multirow{2}{*}{$\begin{array}{l}\text { Dependent variable } \\
\text { Work engagement }(\beta)\end{array}$} \\
\hline & \\
\hline Gender & 0.05 \\
\hline Age & -0.05 \\
\hline Position & 0.03 \\
\hline Tenure & $0.09^{* k \cdot k}$ \\
\hline Promotion focus & $0.20^{* k * k}$ \\
\hline Prevention focus & $0.43^{k+k \cdot k}$ \\
\hline Psychological ownership & $0.21^{\text {k+k-k}}$ \\
\hline Promotion focus ${ }^{*}$ psychological ownership & $-0.16^{*-k}$ \\
\hline Prevention focus*psychological ownership & $0.13^{\text {k*k }}$ \\
\hline $\mathrm{R}^{2}$ & 0.56 \\
\hline Adj- $R^{2}$ & 0.55 \\
\hline $\mathrm{F}$ & $99.40^{*-k-k}$ \\
\hline
\end{tabular}

Note: $\mathrm{N}=716 ;{ }^{* *} \mathrm{p}<0.01,{ }^{* * *} \mathrm{p}<0.001$.

Figure 2 shows that promotion focus cannot effectively and positively influence work engagement in the context of high psychological ownership. In the context of low psychological ownership, promotion focus has a significantly positive impact on work engagement. Notably, the slope of the low psychological ownership group was higher than that of the high psychological ownership group, this means that in the context of low psychological ownership, promotion focus will play a more important role in improving work engagement. Figure 3 shows that in the context of high or low psychological ownership, prevention focus has a positive influence on work engagement. Notably, the slope of the high psychological ownership group was higher than that of the low psychological ownership group, this means that in the context of high psychological ownership, prevention focus pays more attention to the role of improving work engagement. Therefore, hypothesis 9 and hypothesis 10 are supported. 


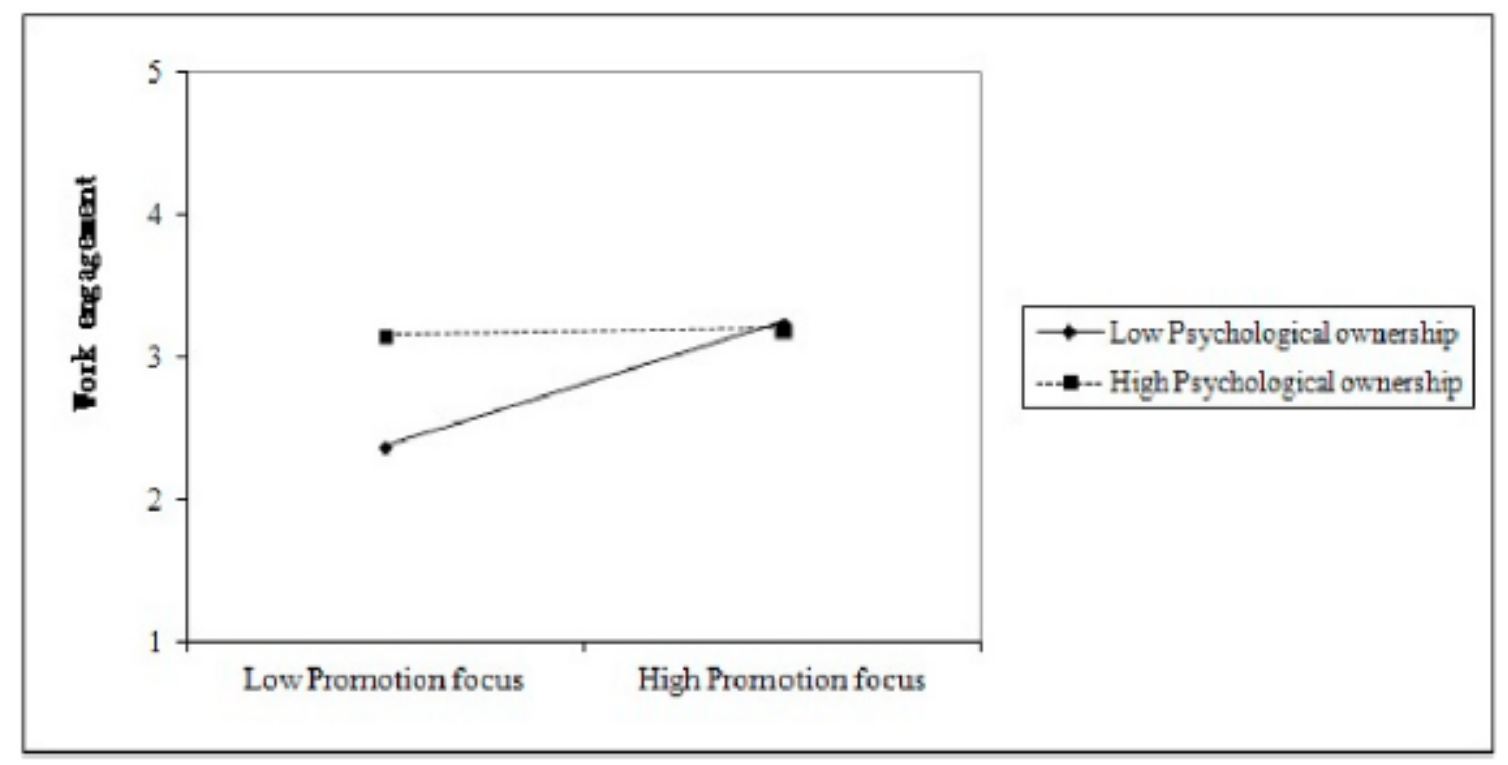

Fig. 2. Moderating effect of psychological ownership on the relationship between promotion focus and work engagement.

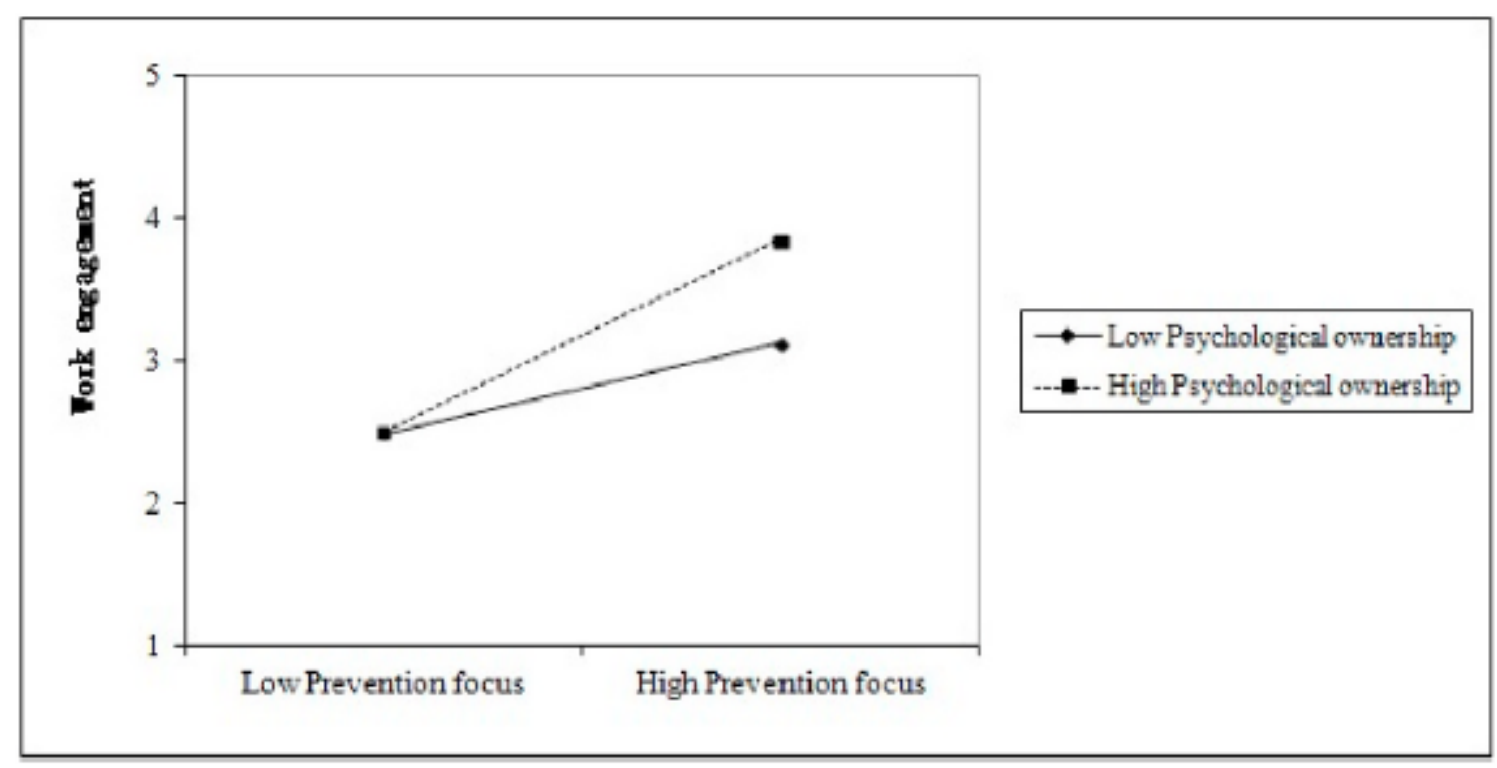

Fig. 3. Moderating effect of psychological ownership on the relationship between prevention focus and work engagement.

Table 8 shows that the interaction between regulatory foci (promotion focus and prevention focus) and psychological ownership significantly predicts job burnout $(\beta=0.13, p<$ $0.05 ; \beta=-0.14, p<0.05$ ), this means psychological ownership has a moderating effect on the 
relationship between regulatory foci (promotion focus and prevention focus) and job burnout. Figure 4 shows that promotion focus cannot effectively reduce job burnout in the context of high psychological ownership. On the contrary, in the context of low psychological ownership, promotion focus has a significantly negative impact on job burnout. This represents that promotion focus is quite important for reducing job burnout in the context of low psychological ownership. Figure 5 shows that in the context of high or low psychological ownership, prevention focus has a negative impact on job burnout. Notably, the slope of the high psychological ownership group was higher than that of the low psychological ownership group. This means that in the context of high psychological ownership, prevention focus is much more important in reducing job burnout. Therefore, hypothesis 11 and hypothesis 12 are supported.

\section{Table 8}

Regression results for moderating role of psychological ownership in the relationship between regulatory foci and job burnout.

\begin{tabular}{|c|c|}
\hline \multirow[t]{2}{*}{ Independent Variables } & \multirow{2}{*}{$\frac{\text { Dependent variable }}{\text { Job burnout }(\beta)}$} \\
\hline & \\
\hline Gender & $-0.13^{* k \cdot k}$ \\
\hline Age & -0.03 \\
\hline Position & -0.03 \\
\hline Tenure & $0.10^{*}$ \\
\hline Promotion focus & -0.12 \\
\hline Prevention focus & $-0.27^{* k \cdot k}$ \\
\hline Psychological ownership & $-0.09^{*}$ \\
\hline Promotion focus* psychological ownership & $0.13^{*}$ \\
\hline Prevention focus ${ }^{*}$ psychological ownership & $-0.14^{*}$ \\
\hline $\mathrm{R}^{2}$ & 0.19 \\
\hline $\operatorname{Adj}-R^{2}$ & 0.18 \\
\hline $\mathrm{F}$ & $18.44^{* * * k}$ \\
\hline
\end{tabular}




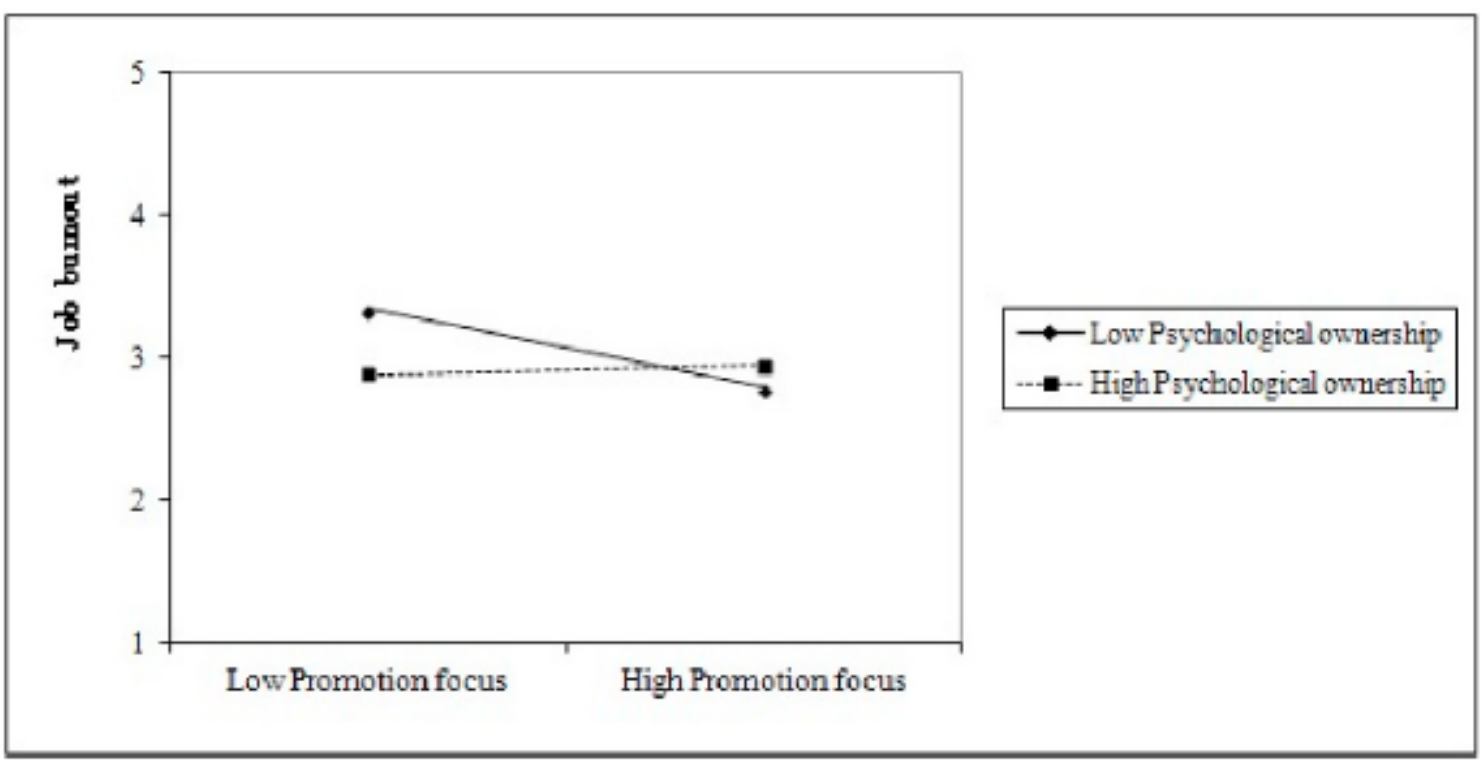

Fig. 4. Moderating effect of psychological ownership on the relationship between promotion focus and job burnout.

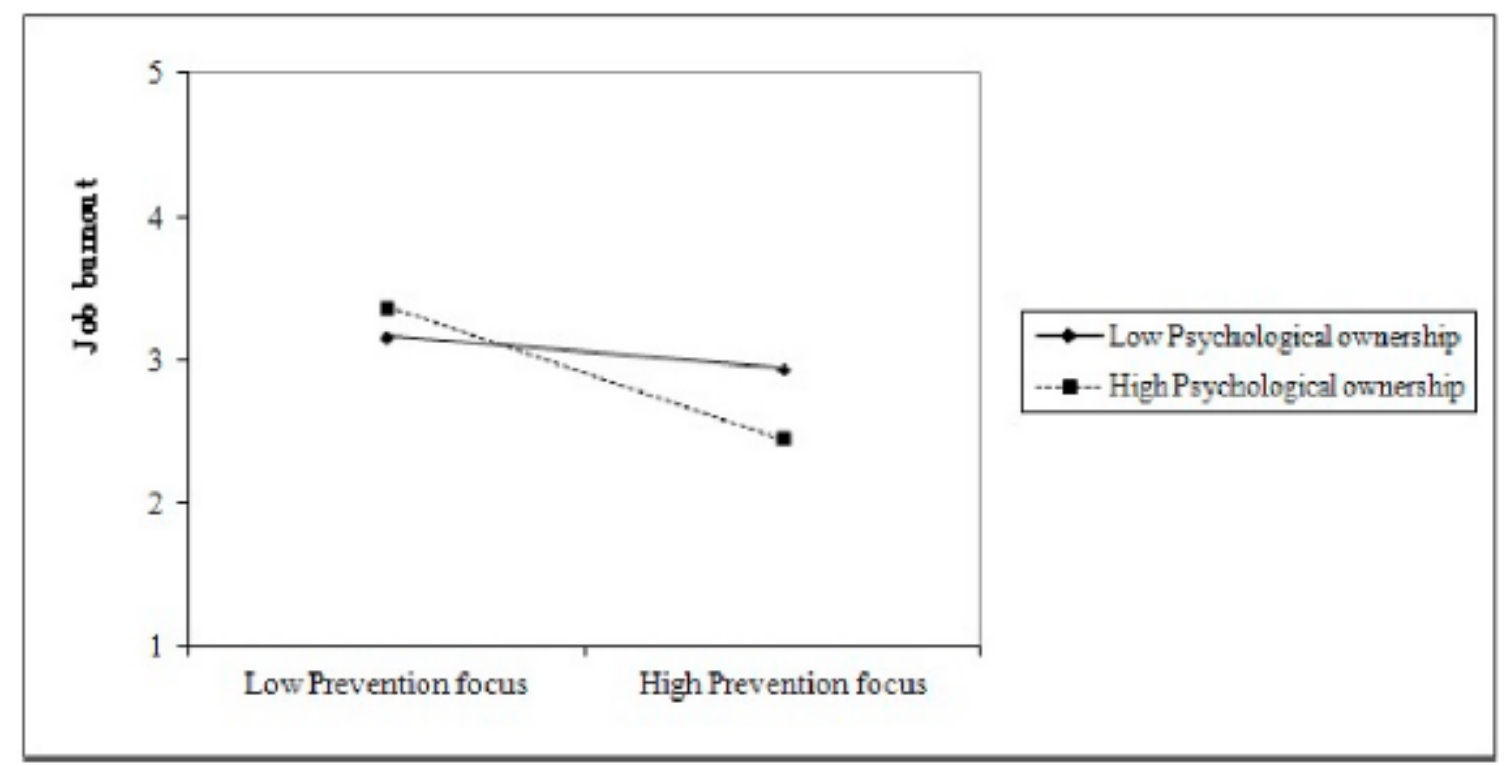

Fig. 5. Moderating effect of psychological ownership on the relationship between prevention focus and job burnout.

\section{Discussion and Conclusion}

\section{Theoretical Implications}

The results show that hypothesis 1 is supported, and this finding echoes the argument of regulatory focus theory. The stronger the promotion focus and prevention focus of hotel 
employees are, the more they will be devoted to their work. In addition, hypothesis 2 is supported. This means that compared with promotion focus, hotel employees' prevention focus is stronger and more helpful to their work engagement. Hypothesis 3 is supported, and this finding also conforms to the argument of regulatory focus theory, this shows that promotion focus and prevention focus can effectively reduce job burnout. hypothesis 4 is supported, which means that compared with promotion focus, hotel employees' prevention focus is much more efficient in reducing job burnout. The findings of this research echo literature on regulatory foci (Jung \& Yoon, 2015; Lin \& Johnson, 2015). This means that employees' regulatory foci will affect their work behavior.

This research finding echoes the views in literature on interactionism (Diener et al., 1984; Endler \& Edwards, 1986). In the field of hospitality and tourism, Dai, Zhuang, and Huan (2019) used the interactionism perspective to explore the influence of resilience (personality) and abusive supervision (contextual factors) on the intention to leave and the work engagement (behaviour) of travel agency employees. In our study, hypothesis 5, 6, 7 and 8 are not supported, indicating that the relationship between regulatory focus, work engagement and job burnout will not be affected by supervisors' organizational embodiment. Hypothesis 9 is supported, and this finding echoes the argument of interactionism. This shows that promotion focus can effectively improve work engagement in the context of low psychological ownership. Hypothesis 10 is supported, and this finding echoes the argument of interactionism. The results show that in the context of high or low psychological ownership, prevention focus has a positive influence on work engagement. Hypothesis 11 is supported, and this finding echoes the argument of interactionism. The results show that promotion focus can effectively reduce job burnout in the context of low psychological ownership. Hypothesis 12 is supported, and this finding echoes the argument of interactionism. The results show that prevention focus can effectively reduce job burnout in both high and low psychological ownership situations. 
In the hospitality or tourism literature, there are many studies on the antecedents of work engagement and job burnout (e.g., Altinay et al., 2019; Karatepe et al., 2014; Lin et al., 2014; Prentice et al., 2013). It seems that it has not been discussed from the perspectives of regulatory foci, supervisors' organizational embodiment and psychological ownership. This study should therefore be able to fill a gap in the literature on hospitality and tourism.

\section{Implications for Managerial Practice}

According to the results of this study, both promotion focus and prevention focus of international tourist hotel staff can help improve their work engagement and reduce their job burnout. Therefore, workplace regulatory focus scale is a good talent evaluation tool for international tourist hotels. International tourist hotel owners may arrange training activities if they are unable to recruit qualified staff. For example, senior staff or supervisors with high promotion focus or high prevention focus are assigned to be the lecturers of training activities. The experience inheritance of these lecturers may contribute to improving the promotion focus or prevention focus of trainees, thereby improving their work engagement or reducing their job burnout.

The results show that psychological ownership has moderating effects on the relationship between regulatory focus, work engagement and job burnout. Although in the context of low psychological ownership, both promotion focus and prevention focus can effectively improve work engagement and reduce job burnout. As can be seen from figure 2, 3, 4 and 5, work engagement scores of the high psychological ownership group were generally higher than those of the low psychological ownership group, the job burnout score in the high psychological ownership group is generally lower than that in the low psychological ownership group. Obviously, international tourist hoteliers must attach importance to the psychological ownership their employees feel toward their companies. In practice, it is feasible to establish 
formal or informal activities that can help improve the psychological ownership of employees. For example, international tourist hoteliers can create a work environment that fosters a sense of belonging. Such as regularly praising employees who work hard and giving appropriate performance bonuses. Even at informal company dinners, supervisors can offer words of encouragement. In this way, the employees' work engagement can be effectively improved and the probability of job burnout can be reduced.

\section{Limitations and Future Research Directions}

In questionnaire design and collecting process of the study, preventive measures were took to reduce the possibility of common method variance (CMV), yet, spurious relationship between variables might still be caused by transverse section design. Such is the limit of the study. To avoid the occurrence, future study could collect different variable data at different time points. Since the sample in this study is a judgmental sample, the results may not be generalized to other context. Future studies can adopt random sampling methods to improve the generalization of our research results. In addition, the study found that the relationship between regulatory focus, work engagement and job burnout was not moderated by supervisors' organizational embodiment. Therefore, in the follow-up study, the supervisors' organizational embodiment can be considered as a mediating variable in the relationship between the regulatory focus, work engagement and job burnout, and this should perfect the research framework. 


\section{References}

Altinay, L., Dai, Y. D., Chang, J., Lee, C. H., Zhuang, W. L., \& Liu, Y.C. (2019). How to facilitate hotel employees' work engagement: The roles of leader-member exchange, role overload and job security. International Journal of Contemporary Hospitality Management, 31(3), 1525-1542.

Anderson, J. C., \& Gerbing, D. W. (1988). Structural equation modeling in practice: A review and recommended two-step approach. Psychological Bulletin, 103(3), 411-423.

Bagozzi, R. P., \& Yi, Y. J. (1988). On the evaluation of structural equation model. Journal of the Academy of Marketing Science, 16(1), 74-94.

Belk, R. W. (1988). Possessions and the extended self. Journal of Consumer Research, 15(2), $139-168$.

Blau, P. M. (1964). Exchange and power in social life. New York, NY: John Wiley.

Brotheridge, C. M., \& Grandey, A. A. (2002). Emotional labor and burnout: comparing two perspectives of "people work". Journal of Vocational Behavior, 60(1), 17-39.

Christian, M. S., Garza, A. S., \& Slaughter, J. E. (2011). Work engagement: A quantitative review and test of its relations with task and contextual performance. Personnel Psychology, 64(1), 89-136.

Dai, Y. D., Hou, Y. H., Chen, K. Y., \& Zhuang, W. L. (2018). To help or not to help: antecedents of hotel employees' organizational citizenship behaviour. International Journal of Contemporary Hospitality Management, 30(3), 1293-1313.

Dai, Y. D., Zhuang, W. L., \& Huan, T. C. (2019). Engage or quit? The moderating role of abusive supervision between resilience, intention to leave and work engagement. Tourism Management, 70, 69-77. 
Diener, E., Larsen, R. J., \& Emmons, R. A. (1984). Person $\times$ situation interactions: Choice of situations and congruence response models. Journal of Personality and Social Psychology, 47(3), 580-592.

Dittmar, H. (1992). The social psychology of material possession: To have is to be. New York, NY: St Martin's Press.

Eisenberger, R., Armeli, S., Rexwinkel, B., Lynch, P., \& Rhoades, L. (2001). Reciprocation of perceived organizational support. Journal of Applied Psychology, 86(1), 42-51.

Eisenberger, R., Huntington, R., Hutchison, S., \& Sowa, D. (1986). Perceived organizational support. Journal of Applied Psychology, 71(3), 500-507.

Eisenberger, R., Karagonlar, G., Stinglhamber, F., Neves, P., Becker, T. E., Gonzalez-Morales, M., \& Steiger-Mueller, M. (2010). Leader-member exchange and affective organizational commitment: The contribution of supervisor's organizational embodiment. Journal of Applied Psychology, 95(6), 1085-1103.

Eisenberger, R., Shoss, M. K., Karagonlar, G., Gonzalez-Morales, M. G., Wickham, R. E., \& Buffardi, L.C. (2014). The supervisor POS-LMX-subordinate POS chain: Moderation by reciprocation wariness and supervisor's organizational embodiment. Journal of Organizational Behavior, 35(5), 635-656.

Endler, N. S., \& Edwards, J. M. (1986). Interactionism in personality in the twentieth century. Personality and Individual Differences, 7(3), 379-384.

Fornell, C., \& Larcker, D. F. (1981). Evaluating structural equation models with unobservable variables and measurement error. Journal of Marketing Research, 18(1), 39-50.

Freudenberger, H. J. (1974). Staff burn-out. Journal of Social Issues, 30(1), 159-165.

Grobler, P. A., Wärnich, S., Carrell, M. R., Elbert, N. F., \& Hatfield, R. D. (2002). Human resource management in South Africa (2nd ed.). London, UK: Thomson. 
Guan, X., Yeh, S.S., Chiang, T.Y., \& Huan, T.C. (2020). Does organizational inducement foster work engagement in hospitality industry? Perspectives from a moderated mediation model. Journal of Hospitality and Tourism Management, 43, 259-268.

Hair, J. F., Anderson, R. E., Tatham, R. L., \& Black, W. C. (1998). Multivariate data analysis (5th ed). Upper Saddle River, NJ: Prentice Hall.

Han, T. S., Chiang, H. H., \& Chang, A. (2010). Employee participation in decision making, psychological ownership and knowledge sharing: mediating role of organizational commitment in Taiwanese high-tech organizations. International Journal of Human Resource Management, 21(12), 2218-2233.

Higgins, E. T. (1996). The "self digest": Self-knowledge serving self-regulatory functions. Journal of Personality and Social Psychology, 71(6), 1062-1083.

Higgins, E. T. (1997). Beyond pleasure and pain. American Psychologist, 52(12), 1280-1300.

Higgins, E. T., Friedman, R. S., Harlow, R. E., Idson, L. C., Ayduk, O. N., \& Taylor, A. (2001). Achievement orientations from subjective histories of success: Promotion pride versus prevention pride. European Journal of Social Psychology, 31(1), 3-23.

Johnson, H. A. M., \& Spector, P. E. (2007). Service with a smile: do emotional intelligence, gender, and autonomy moderate the emotional labor process? Journal of Occupational Health Psychology, 12(4), 319-333.

Jung, H. S., \& Yoon, H. H. (2015). Understanding regulatory focuses the role of employees' regulatory focus in stress coping styles, and turnover intent to a five-star hotel. International Journal of Contemporary Hospitality Management, 27(2), 283-307.

Kalimo, R., Pahkin, K., Mutanen, P., \& Toppinen-Tanner, S. (2003). Staying well or burning out at work: Work characteristics and personal resources as long-term predictors. Work and Stress, 17(2), 109-122. 
Karatepe, O. M., Beirami, E., Bouzari, M., \& Safavi, H. P. (2014). Does work engagement mediate the effects of challenge stressors on job outcomes? Evidence from the hotel industry. International Journal of Hospitality Management, 36, 14-22.

Karatepe, O. M., Keshavarz, S., \& Nejati, S. (2010). Do core self-evaluations mediate the effect of coworker support on work engagement? A study of hotel employees in Iran. Journal of Hospitality and Tourism Management, 17(1), 62-71.

Li, X., Sanders, K., \& Frenkel, S. (2012). How leader-member exchange, work engagement and HRM consistency explain Chinese luxury hotel employees' job performance. International Journal of Hospitality Management, 31(4), 1059-1066.

Lin, S. H. J., \& Johnson, R. E. (2015). A suggestion to improve a day keeps your depletion away: Examining promotive and prohibitive voice behaviors within a regulatory focus and ego depletion framework. Journal of Applied Psychology, 100(5), 1381-1397.

Lin, Y. S., Huang, W. S., Yang, C. T., \& Chiang, M. J. (2014). Work-leisure conflict and its associations with well-being: The roles of social support, leisure participation and job burnout. Tourism Management, 45, 244-252.

Mansour, S., \& Tremblay, D.-G. (2016). How the need for "leisure benefit systems" as a "resource passageways" moderates the effect of work-leisure conflict on job burnout and intention to leave: A study in the hotel industry in Quebec. Journal of Hospitality and Tourism Management, 27, 4-11.

Maslach, C., \& Jackson, S. E. (1986). The Maslach Burnout Inventory (2nd ed.). Palo Alto, CA: Consulting Psychologist Press.

Maslach, C., \& Jackson, S. E. (1984). Burnout in organizational settings. Applied Social Psychology Annual, 5, 133-135. 
Montgomery, A. J., Panagopolou, E., de Wildt, M., \& Meenks, E. (2006). Work-family interference, emotional labor and burnout. Journal of Managerial Psychology, 21(1), 3651.

Pang, L., Kucukusta, D., \& Chan, X. (2015). Employee turnover intention in travel agencies: analysis of controllable and uncontrollable factors. International Journal of Tourism Research, 17(6), 577-590.

Pienaar, J., \& Willemse, S. A. (2008). Burnout, engagement, coping and general health of service employees in the hospitality industry. Tourism Management, 29(6), 1053-1063.

Pierce, J. L., Kostova, T., \& Dirks, K. T. (2001). Toward a theory of psychological ownership in organizations. Academy of Management Review, 26(2), 298-310.

Podsakoff, P. M., MacKenzie, S. B., \& Podsakoff, N. P. (2012). Sources of method bias in social science research and recommendations on how to control it. Annual Review of Psychology, 63, 539-569.

Prentice, C., Chen, P. J., \& King, B. (2013). Employee performance outcomes and burnout following the presentation-of-self in customer-service contexts. International Journal of Hospitality Management, 35, 225-236.

Schaufeli, W. B., Bakker, A. B., \& Salanova, M. (2006). The measurement of work engagement with a short questionnaire: a cross-national study. Educational and Psychological Measurement, 66(4), 701-716.

Schaufeli, W. B., Salanova, M., Gonzáles-Romá, V., \& Bakker, A. B. (2002). The measurement of engagement and burnout: A two sample confirmatory factor analytic approach. Journal of Happiness Studies, 3(1), 71-92.

Shoss, M. K., Eisenberger, R., Restubog, S. L. D., \& Zagenczyk, T. J. (2013). Blaming the organization for abusive supervision: The roles of perceived organizational support and supervisor's organizational embodiment. Journal of Applied Psychology, 98(1), 158-168. 
Van Dyne, L., \& Pierce, J. L. (2004). Psychological ownership and feeling of possession: Three field studies predicting employee attitudes and organizational citizenship behaviour. Journal of Organizational Behavior, 25(4), 439-459.

Wallace, J. C., \& Chen, G. (2006). A multilevel integration of personality, climate, selfregulation, and performance. Personnel Psychology, 59(3), 529-557.

Walters, G., \& Raybould, M. (2007). Burnout and perceived organisational support among front-line hospitality employees. Journal of Hospitality and Tourism Management, 14(2), 144-156. 
Table 1 First-Order Confirmatory Factor Analysis Results

\begin{tabular}{lcc}
\hline Items & SFL & t-value \\
\hline Promotion focus & & \\
I can always do a lot of work & 0.82 & - \\
Anyway, I have to finish my work & 0.83 & 26.50 \\
can do a lot of work in a short time & 0.83 & 26.64 \\
Work tasks can make me better at work & 0.84 & 27.09 \\
I often wonder if my work is done & 0.80 & 24.97 \\
I always think about how much work I can accomplish & 0.82 & 26.00
\end{tabular}

\section{Prevention focus}

$0.67 \quad 0.93$

I often follow the rules to work

0.81

I often complete work tasks correctly

$0.86 \quad 27.10$

I always do my job duty

$0.86 \quad 27.14$

When working, I often think of my duties

$0.81 \quad 25.06$

I often finish my job

$0.78 \quad 23.77$

I often notice work details

$0.80 \quad 24.38$

\section{Supervisors' organizational embodiment}

0.81

0.95

My supervisor has the spirit of the company

0.89

My supervisor has many similarities with my company

0.91

36.92

My supervisor and the company have the same standards for me

0.89

35.32

My supervisor can represent my company

$0.90 \quad 36.20$

My supervisor is very similar to my company

$0.90 \quad 36.00$

\section{Psychological ownership}

0.80

0.92

I think the company I am staying with is my company

0.88

I think the success or failure of the company, I am deeply involved

0.91

33.76

I would like to see the company as my home

0.89

33.10

\section{Work engagement}

$0.70 \quad 0.95$

I am motivated at work

0.86

In my job position, I consider myself handy and energetic

$0.84 \quad 29.07$

I am passionate about my work

$0.89 \quad 32.87$

My job inspired me

$0.89 \quad 32.47$

When I get up in the morning, I really want to go to work

0.77

25.62

I feel happy when I am busy with work

$0.84 \quad 29.62$

I am proud of my work

$0.86 \quad 30.46$ 
I am very focused on my work

I overdo it at work
0.81

0.77

\section{Emotional exhaustion}

My job makes me tired

I feel exhausted after work

When I got up, I was tired of thinking about what I am doing today

Working with the crowd all day makes me feel tired

I'm tired of my work

I am frustrated with my work

I think my work is hard

Working with people puts me under a lot of pressure

I think I have reached the limit
0.79

0.97

0.87

0.87

33.39

$0.89 \quad 34.77$

$0.91 \quad 36.33$

$0.93 \quad 38.57$

$0.92 \quad 37.53$

$0.88 \quad 33.68$

$0.90 \quad 35.50$

$0.80 \quad 28.39$

$0.70 \quad 0.92$

0.83

$0.86 \quad 28.24$

$0.84 \quad 27.04$

$0.85 \quad 27.43$

$0.81 \quad 25.76$

\section{Reduced personal accomplishment}

Whenever I have close contact with others, I cannot feel happy

0.88

I rarely accomplish anything of value in this job

0.89

$0.90 \quad 36.39$

I can't calmly deal with my emotional problems at work

I think my attitude towards some people is cold

$0.90 \quad 36.99$

After I got this job, I became less emotional about others

$0.93 \quad 40.15$

I worry that this job will make me more and more ruthless

0.93

40.19

I don't care what happened to others

0.91

37.92

I think others blame me for their own problems

0.88

Note: SFL: standardised factor loading; AVE: average variance extracted; CR: composite reliability 
Table 2 Mean, Standard Error, Square Root of AVE and Correlation Coefficients

\begin{tabular}{|c|c|c|c|c|c|c|c|c|c|c|}
\hline Variables & Mean & $\begin{array}{c}\text { Standard } \\
\text { error }\end{array}$ & A & B & $\mathrm{C}$ & $\mathrm{D}$ & $\mathrm{E}$ & $\mathrm{F}$ & $\mathrm{G}$ & $\mathrm{H}$ \\
\hline A. Promotion focus & 4.01 & 0.63 & $\begin{array}{c}0.82 \\
1\end{array}$ & & & & & & & \\
\hline B. Prevention focus & 4.08 & 0.62 & 0.81 & $\begin{array}{c}0.82 \\
1\end{array}$ & & & & & & \\
\hline $\begin{array}{l}\text { C. Supervisors' } \\
\text { organizational } \\
\text { embodiment }\end{array}$ & 3.93 & 0.73 & 0.46 & 0.45 & $\begin{array}{c}0.90 \\
1\end{array}$ & & & & & \\
\hline $\begin{array}{l}\text { D. Psychological } \\
\text { ownership }\end{array}$ & 3.46 & 0.83 & 0.41 & 0.39 & 0.43 & $\begin{array}{c}0.89 \\
1\end{array}$ & & & & \\
\hline E. Work engagement & 3.80 & 0.73 & 0.66 & 0.69 & 0.47 & 0.47 & $\begin{array}{c}0.84 \\
1\end{array}$ & & & \\
\hline $\begin{array}{r}\text { F. Emotional } \\
\text { exhaustion }\end{array}$ & 2.44 & 0.77 & $0 . \overline{29}$ & $0 . \overline{29}$ & $0 . \overline{23}$ & $0 . \overline{25}$ & $0 . \overline{2} 8$ & $\begin{array}{c}0.89 \\
1\end{array}$ & & \\
\hline G. Depersonalization & 2.27 & 0.74 & $0 . \overline{34}$ & $0 . \overline{38}$ & $0 . \overline{30}$ & $0 . \overline{20}$ & $0 . \overline{37}$ & 0.70 & $\begin{array}{c}0.84 \\
1\end{array}$ & \\
\hline $\begin{array}{l}\text { H. Reduced personal } \\
\text { accomplishment }\end{array}$ & 2.15 & 0.75 & $0 . \overline{35}$ & $0 . \overline{36}$ & $0 . \overline{28}$ & $0 . \overline{20}$ & $0 . \overline{3}$ & 0.63 & 0.81 & $\begin{array}{c}0.90 \\
1 \\
\end{array}$ \\
\hline
\end{tabular}

Note: The value of the diagonal (the bold part of the slash) represents the square root of AVE, and the numerical value below the diagonal is the standardised correlation coefficient.

Table 3 Multiple Regression Analysis of Regulatory Foci for Work Engagement

\begin{tabular}{|c|c|}
\hline $\begin{array}{l}\text { Independent } \\
\text { variables }\end{array}$ & Work engagement \\
\hline Gender & 0.05 \\
\hline Age & -0.02 \\
\hline Position & 0.04 \\
\hline Tenure & $0.10 * *$ \\
\hline Promotion focus & $0.27 * * *$ \\
\hline Prevention focus & $0.45^{* * *}$ \\
\hline $\mathrm{R}^{2}$ & 0.52 \\
\hline Adj-R ${ }^{2}$ & 0.52 \\
\hline $\mathrm{F}$ & $128.22 * * *$ \\
\hline
\end{tabular}

Note: $\mathrm{N}=716 ; * * \mathrm{p}<0.01, * * * \mathrm{p}<0.001$ 
Table 4 Multiple Regression Analysis of Regulatory Foci for Job Burnout

$\begin{array}{r}\text { Dependent } \\ \text { variable } \\ \text { variables }\end{array}$
Gender

Note: $\mathrm{N}=716 ;{ }^{*} \mathrm{p}<0.05, * * * \mathrm{p}<0.001$

Table 5 Regression results for moderating role of Supervisors' organizational embodiment in the relationship between regulatory foci and work engagement

$\begin{array}{r}\text { Dependent } \\ \text { variable }\end{array}$
Wender
Age
Position
Tenure
Promotion focus
Prevention focus
Priables


Note: $\mathrm{N}=716 ; * * * \mathrm{p}<0.001$

Table 6 Regression results for moderating role of Supervisors' organizational embodiment in the relationship between regulatory foci and job burnout

\begin{tabular}{|c|c|}
\hline $\begin{array}{l}\begin{array}{r}\text { Dependent } \\
\text { variable } \\
\text { variables }\end{array} \\
\text { varent }\end{array}$ & Job burnout \\
\hline Gender & $-0.13 * * *$ \\
\hline Age & -0.04 \\
\hline Position & -0.02 \\
\hline Tenure & $0.08 *$ \\
\hline Promotion focus & -0.11 \\
\hline Prevention focus & $-0.24 * * *$ \\
\hline Supervisors' organizational embodiment & $-0.14 * * *$ \\
\hline $\begin{array}{c}\text { Promotion focus*supervisors' organizational } \\
\text { embodiment }\end{array}$ & -0.08 \\
\hline $\begin{array}{c}\text { Prevention focus*supervisors' organizational } \\
\text { embodiment }\end{array}$ & 0.08 \\
\hline $\mathrm{R}^{2}$ & 0.20 \\
\hline Adj-R ${ }^{2}$ & 0.19 \\
\hline $\mathrm{F}$ & $19.01 * * *$ \\
\hline
\end{tabular}

Note: $\mathrm{N}=716 ;{ }^{*} \mathrm{p}<0.05, * * * \mathrm{p}<0.001$

Table 7 Regression results for moderating role of psychological ownership in the relationship between regulatory foci and work engagement

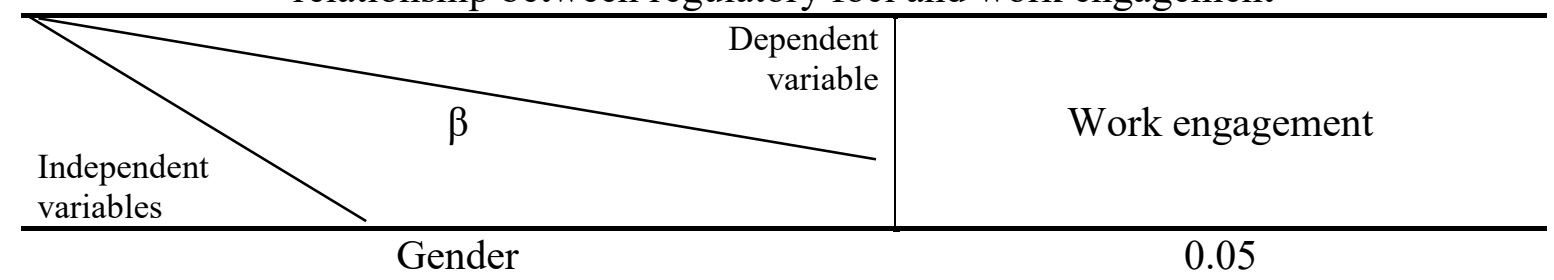




$\begin{array}{cc}\text { Age } & -0.05 \\ \text { Position } & 0.03 \\ \text { Tenure } & 0.09^{* *} \\ \text { Promotion focus } & 0.20^{* * *} \\ \text { Prevention focus } & 0.43^{* * *} \\ \text { Psychological ownership } & 0.21^{* * *} \\ \text { ion focus* psychological ownership } & -0.16^{* *} \\ \text { ion focus* }{ }^{*} \text { psychological ownership } & 0.13^{* *} \\ \mathrm{R}^{2} & 0.56 \\ \text { Adj-R } & 0.55 \\ \mathrm{~F} & 99.40^{2 * *}\end{array}$

Note: $\mathrm{N}=716 ;{ }^{* *} \mathrm{p}<0.01, * * * \mathrm{p}<0.001$

Table 8 Regression results for moderating role of psychological ownership in the relationship between regulatory foci and job burnout

\begin{tabular}{|c|c|}
\hline $\begin{array}{rr} & \begin{array}{r}\text { Dependent } \\
\text { variable }\end{array} \\
\beta\end{array}$ & Job burnout \\
\hline Gender & $-0.13 * * *$ \\
\hline Age & -0.03 \\
\hline Position & -0.03 \\
\hline Tenure & $0.10^{*}$ \\
\hline Promotion focus & -0.12 \\
\hline Prevention focus & $-0.27 * * *$ \\
\hline Psychological ownership & $-0.09 *$ \\
\hline Promotion focus*psychological ownership & $0.13 *$ \\
\hline Prevention focus*psychological ownership & $-0.14 *$ \\
\hline $\mathrm{R}^{2}$ & 0.19 \\
\hline Adj- $R^{2}$ & 0.18 \\
\hline $\mathrm{F}$ & $18.44 * * *$ \\
\hline
\end{tabular}

$\mathrm{N}=716 ; * * \mathrm{p}<0.01, * * * \mathrm{p}<0.001$ 


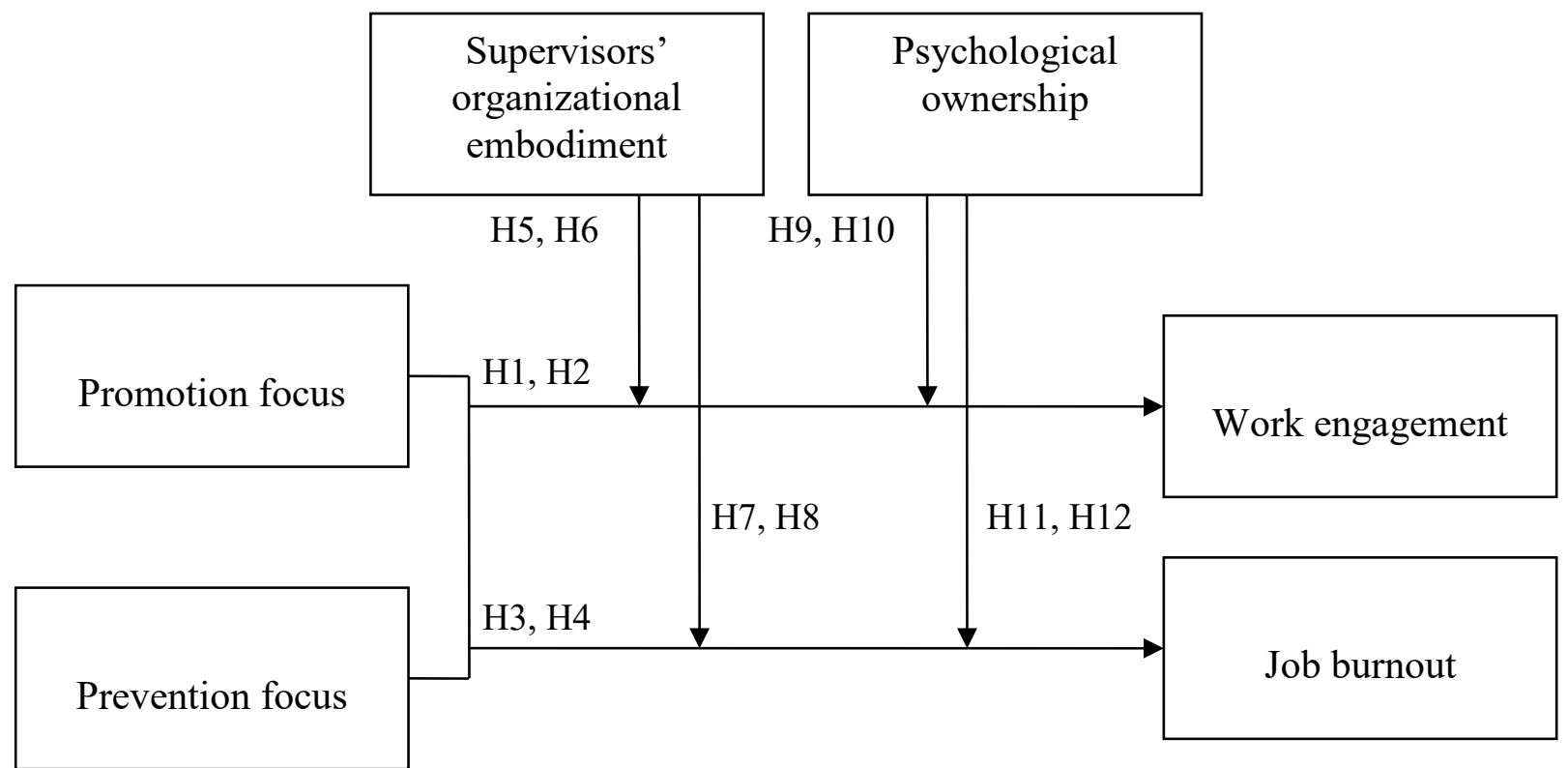

Figure 1 Conceptual framework

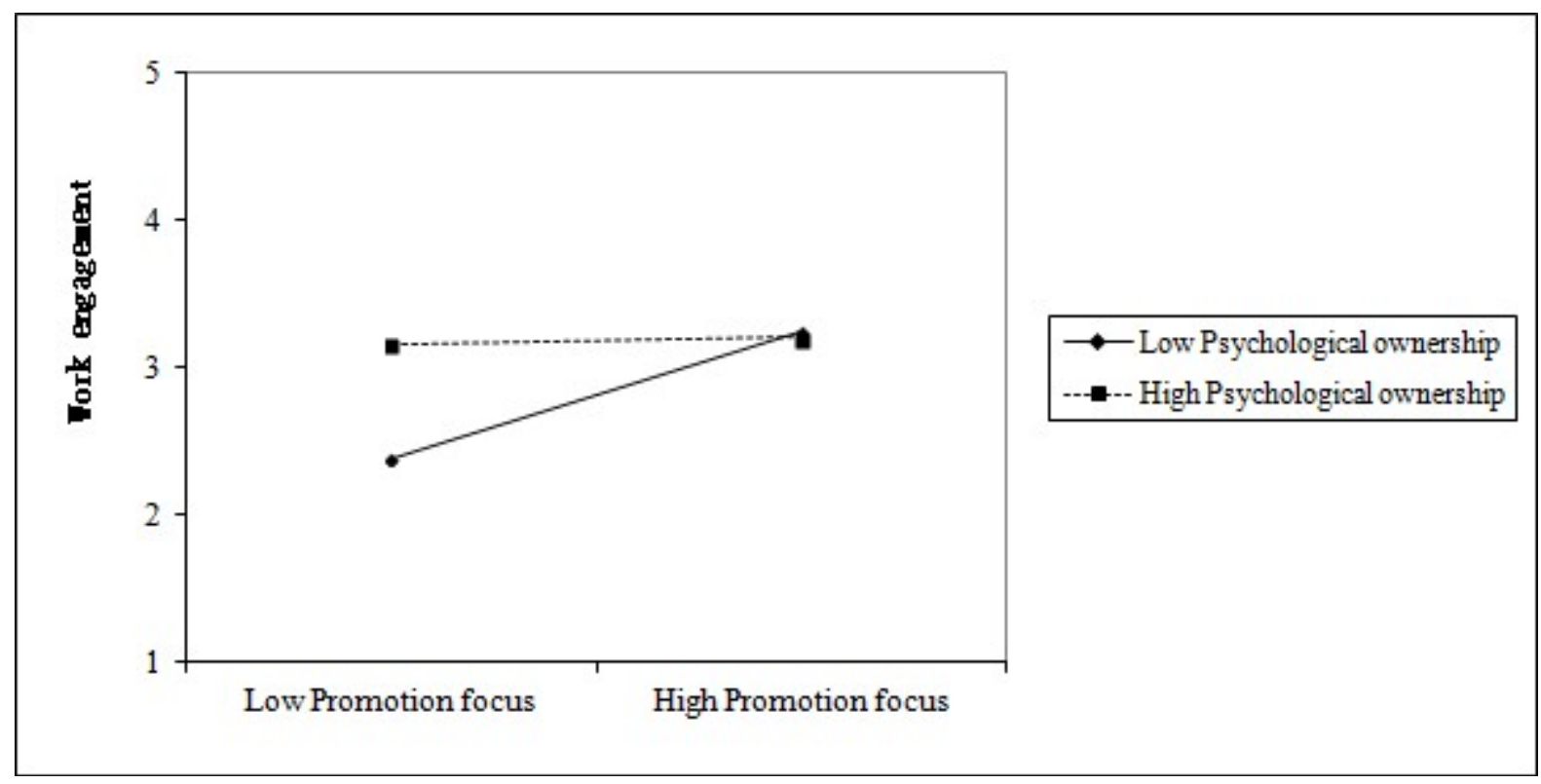

Figure 2 Moderating effect of psychological ownership on the relationship between promotion focus and work engagement 


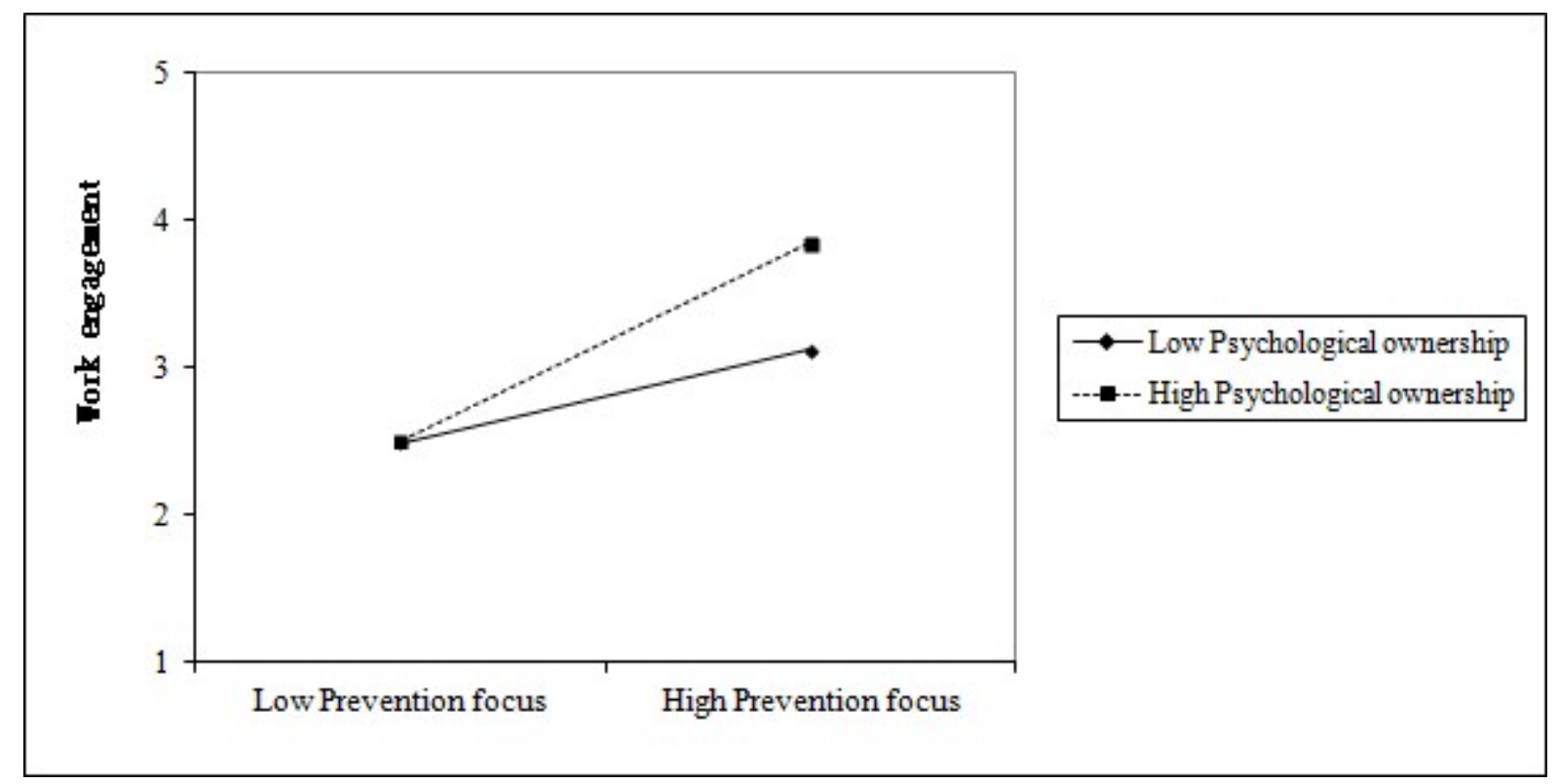

Figure 3 Moderating effect of psychological ownership on the relationship between prevention focus and work engagement

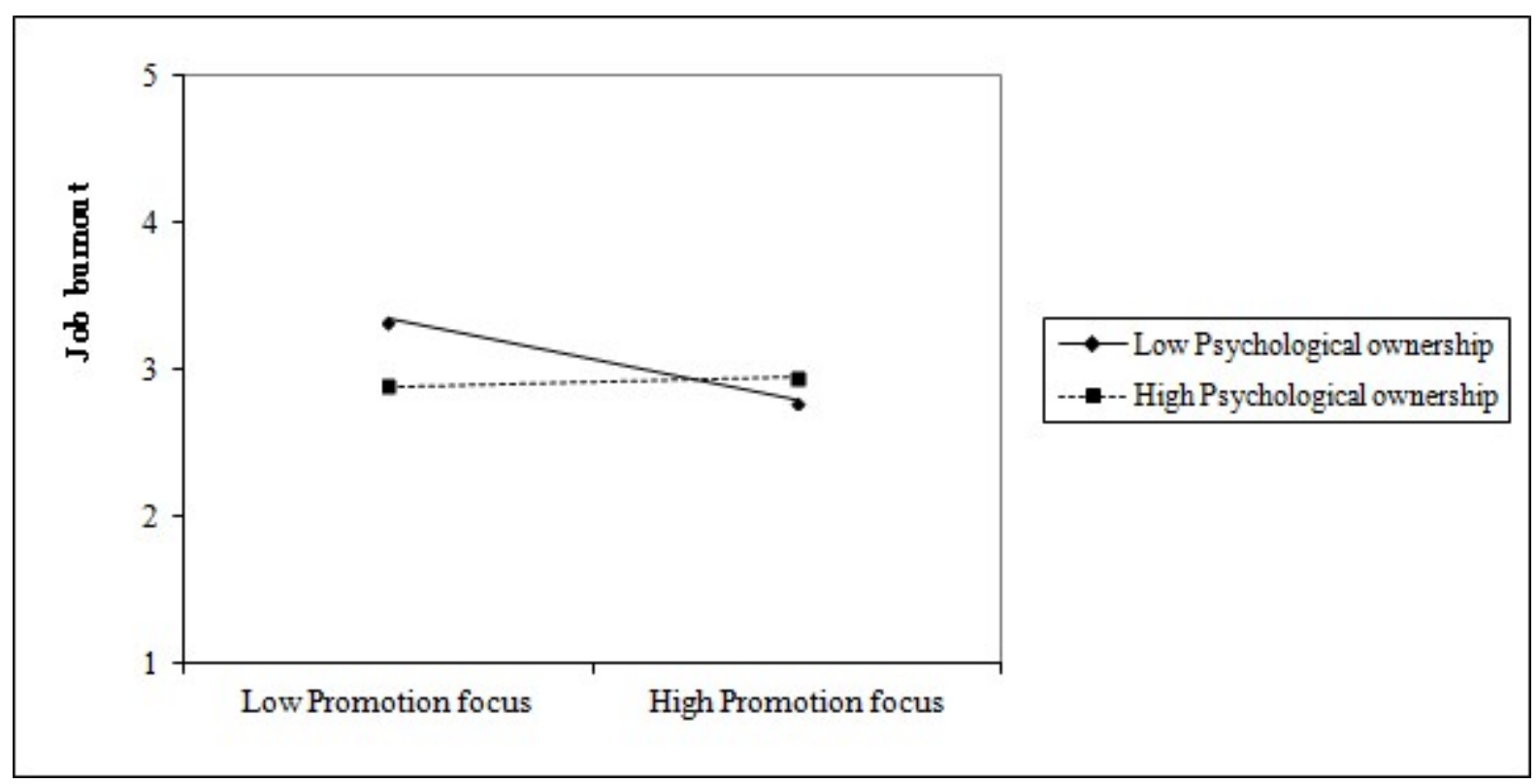

Figure 4 Moderating effect of psychological ownership on the relationship between promotion focus and job burnout 


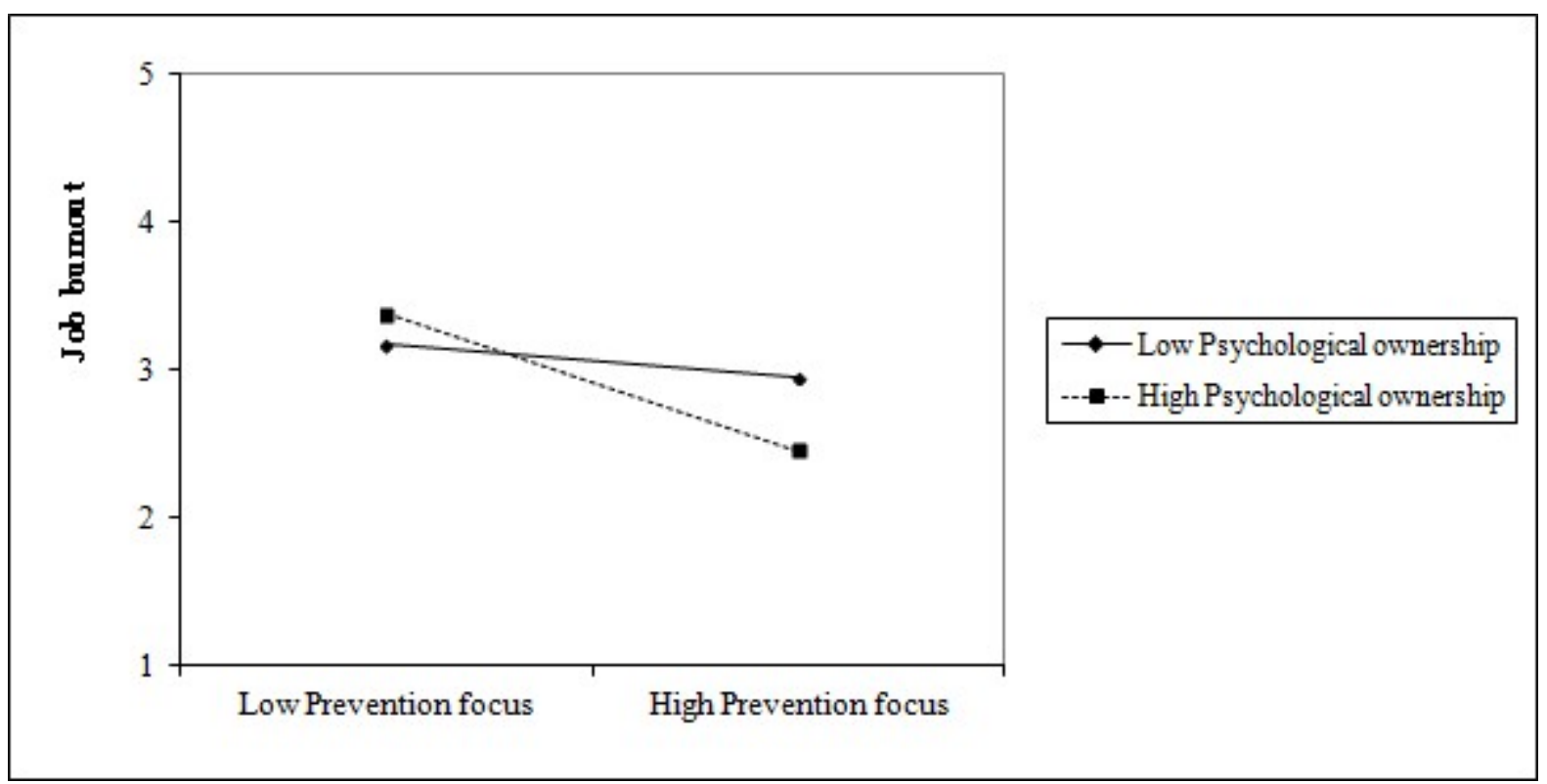

Figure 5 Moderating effect of psychological ownership on the relationship between prevention focus and job burnout 